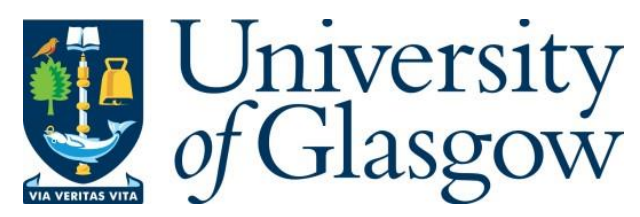

Dick, M.-D. (2016) The two Jameses: a Joycean politics of criticism as commemoration. Irish Studies Review, 24(4), pp. 396-406.

There may be differences between this version and the published version. You are advised to consult the publisher's version if you wish to cite from it.

http://eprints.gla.ac.uk/128886/

Deposited on: 26 September 2016

Enlighten - Research publications by members of the University of Glasgow http://eprints.gla.ac.uk 


\title{
The Two Jameses: A Joycean Politics of Criticism as Commemoration
}

\section{Maria-Daniella Dick}

\author{
English Literature, University of Glasgow
}

[I]t seems to us that some historical and cultural situations are likely to overdetermine readings of Joyce much more interestingly and appropriately than others, that there may be particular times and places in which Joyce's work can be better understood than others. ${ }^{1}$

This is brave Danny weeping his spache for the popers. This is cool Connolly wiping his hearth with brave Danny. And this, regard! how Chawleses Skewered parparaparnelligoes between brave Danny boy and the Connolly. ${ }^{2}$

\section{The "London Method" and The "Irish Method"}

We feel in England that we have treated you rather unfairly. It seems history is to blame. ${ }^{3}$

The first epigraph to this article is taken from Andrew Gibson and Len Platt's Introduction to Joyce, Ireland, Britain, in which the editors discuss a genealogy of Joyce criticism with regard to the relative "burden of history" within the work of James Joyce. ${ }^{4}$ Gibson and Platt advocate an historical method of textual analysis practised by what they term the "London school"' of Joycean criticism, to which both belong and which they characterise according to a materialist focus that privileges history in text while eschewing the lens of theory. "It relies," they write, “on a practice of historical concretion” whereby "particulars take precedence over abstractions," and on a "practice of historical saturation" whereby the maximum historical information is brought to bear upon the text. " "This information," therefore, "has priority over everything else except the texts" ${ }^{6}$ The methodology is contrasted to what they term, by contrast, the "Irish method," which the editors suggest is both historically and culturally overdetermined by what they identify as a "prospective drive," defined as follows: "the invention of Ireland, the will to modernity, syncretism". ${ }^{7}$ In this depiction the prospective drive towards modernity characterises both a branch of Joyce criticism and an approach to history: the "Irish method". Gibson and Platt locate their methodology in a post-theoretical historical turn to materialism, situating readings of (for example) Ulysses in the context of its textual setting as opposed to that of its textual production, and thereby avoiding what they consider a future trajectory into modern Europe from the historicity of Dublin 1904. While deeming the compulsion to such an approach understandable "from an Irish perspective", the editors assert that their responsibility is to resist surrendering to "historical amnesia” and to pay a debt to history through historical reading; this is framed as an ethical issue by means of which the question of a "contemporary historical atonement" might be answered, precisely because Gibson and Platt consider this the responsibility of the "new kind of English Joyce scholar," who is able to do "extremely hard and painstaking historical work" in order to resist forgetting and acknowledge that debtorship. ${ }^{8}$

More recently, however, the two strands as determined by Gibson and Platt have attained another dimension. In January 2015 Ronan McGreevy reported in The Irish Times from the Theatre of War symposium held at the Abbey Theatre, outlining Luke Gibbons' position on the Easter Rising as an event of 
radical global political significance; citing the Freudian concept of Nachträglichkeit, or 'belatedness', Gibbons argued against the concentration in the official programme of commemoration on historical records as opposed to literary accounts, positing that trauma relies on artistic representation to be processed and therefore can only be understood after the fact, through a representation and transmission of memory that offers a context for understanding events. ${ }^{9}$

Gibson and Platt's "prospective drive” as marker of an Irish criticism finds echoes in the idea that history is received as such belatedly and via its working through in art; Gibbons is one of the critics singled out in their advocacy of historical reading, as an exemplar of the Irish critic who seeks to create a Joyce who is both Irish and national, European and modern. Yet Gibbons insists on the importance of literary representation to comprehension of history generally and of the Rising specifically; in this sense, representation constructs history and history cannot be contextualised in solely documentary modes nor thought on purely contemporary grounds. As Gibbons argues as recently as in his new 2015 monograph Joyce's Ghosts, Joyce's modernity is not in opposition to his Irishness and thus to Irish history: the two are co-implicated. Gibson and Platt, on the other hand, propose a methodology that implies a reading of the text as historical document, and therefore history as an a priori reflected in the text. The possibility of an ethical gesture and postcolonial view of history is predicated upon an empirical reading of Joyce, whereby history becomes a means to alleviate historical debt and to navigate past the Hainesian denial captured in the epigraph to this section, the colonial position of the English usurper admitted into the Martello Tower by Buck Mulligan at the beginning of Ulysses.

Whether from a national, historical or postcolonial perspective, there is now a significant body of work on Joyce in relation to Irish politics. The first of these approaches was in the 1980s, with Joyce's Politics by Dominic Mangianello (1980). In the 1990s James Fairhall's James Joyce and the Question of History (1993), Emer Nolan's Joyce and Nationalism (1995), Vincent Cheng's Joyce, Race and Empire (1995) and Trevor L. Williams's Reading Joyce Politically (1997) exemplified the field; they were followed by in the millennium by Gibson's Joyce's Revenge: History, Politics and Aesthetics in Ulysses (2002) and The Strong Spirit: History, Politics and Aesthetics in the Writings of James Joyce (2013) which, along with the co-edited volume with Platt, outline both an historical ideology and methodology. Other recent work includes that such as the previously cited Joyce's Ghosts, published in 2015 and distinctly located within the modernist trajectory as characterised by Gibson and Platt. One might consider this an internecine debate from within an institutional field, albeit one which, owing to the significance of that field, indexes wider disciplinary debates. However, the question of the politics of Joyce, and the interrelated question of a politics of Joycean criticism, here read as refracted through the former, is also pertinent to examining the way in which politics is encoded. This determination of methodological approaches by Gibson and Platt, the two alternatives posited for James - or two Jameses as it were, the Irish and the London Joyce (a tacit silence on the discrepancy between the national versus the metropolitan noted here in passing) - is particularly salient in 2016, an historical juncture which might be considered another moment that is, in various ways, overdetermined in its reading. As such, and to echo Gibson and Platt, it offers the possibility not only of 
reading Joyce in an interesting way but of reappraising the relationship of Joycean reading to the historicocultural situation of commemoration.

\section{Two Jameses, redux}

The 2016 XXV Joyce Symposium was entitled simply “Anniversary Joyce,” a title that suggestively alludes to the centenary of the publication date of A Portrait of the Artist as a Young Man (1916) as well as to the global historical events with whose commemorations it deliberately intersects, the Easter Rising and the Battle of the Somme. If there are two Jameses presented by Gibson and Platt, there are also then another two Jameses through which this reading may be effected: James Joyce and James Connolly. The title of this article may nonetheless indicate connection where apparently there is none, or at most a minimal availability to interpretation. When considering aesthetic representations of Connolly, those examples which immediately predominate are those in which he is explicitly commemorated or presented: W. B. Yeats's “Easter, 1916” (1916) and “The Rose Tree” (1921), Seán O'Casey's The Plough and the Stars (1926), “The Weapon” (1930) of Hugh MacDiarmid, Somhairle MacGill-Eain/Sorley MacLean's “The National Museum of Ireland”/ “Àrd-Mhusaeum na h- Èireann” (1970) and, latterly, Roddy Doyle's A Star Called Henry (1999). On the other hand, Joyce does not engage in any explicit fashion with the figure of James Connolly; the engagement, such as it is, is obscured. As I will argue, it is thus not Joyce's work itself but Joycean criticism that brings out the relationship between the two, and I wish to suggest that critical opinion in Joyce studies focuses on what might be called this non-place of Connolly in Joyce's work as a way of engaging the former with the latter and bringing him into presence, creating a relationship from silence and absence that then allows the reader to reflect upon the place of that criticism in commemorating Connolly.

Subsequent to Mangianello's monograph, the first ostensibly explicit consideration of the two is in a 1986 article by George Dangerfield; entitled and apparently devoted to the relationship between "James Joyce, James Connolly and Irish Nationalism,” it is instead a history of Connolly that gestures to the "Cyclops" chapter of Ulysses to make analogies between Joyce's nationalism and that of Connolly. Direct references in Finnegans Wake are scant: Roland McHugh cites two mentions, one in Book I.iii to Connolly's 1914 treatise Ireland on the Dissecting Table - which becomes, in Wakean language, "Hyland on the dissenting table” - and a later mention in II.ii to a litany of Irish heroes including Daniel O'Connell and Charles Stewart Parnell, cited above in the second epigraph to this article. ${ }^{10}$ In James Joyce and the Question of History, James Fairhall draws attention to the reworking of Connolly's "Ireland sober is Ireland free" (itself a reformulation of George Leahy) in the Wake as "Ireland sober is Ireland stiff”. ${ }^{11}$

Where Connolly appears in Joyce, if at all, it is as a ghost called into presence through suggestive absence and, I suggest, a drive to commemoration in critical readings inscribed in a politics of Joyce. What is therefore at stake is not how Joyce himself incorporates and commemorates Connolly, but how criticism commemorates Connolly in and through Joyce, establishing its own position. Fairhall begins his account linking the two Jameses by stating that “Joyce made no recorded reference to James Connolly". ${ }^{12}$ This caveat dispensed, he suggests that "[t]his is surprising, and it seems to me even more surprising that there should not be a powerful connection between Connolly and Colgan, the Labour candidate in "Ivy Day."” - the latter 
referring to "Ivy Day in the Committee Room”, the story from Dubliners, set in 1902, that ostensibly serves as both a commemoration of Parnell and an indictment of post-Parnellite national politics. ${ }^{13}$ Fairhall goes on to claim such a connection founded on what he perceives to be the socialist aspect of the election campaign upon which the story is based, arguing that the participation of Connolly in the 1902 and 1903 Dublin elections is contained in the story through reference to an off-stage character, the Labour candidate Colgan, "as a subtext which reflects not only the conflict between Irish middle-class nationalism and Irish labor, but the contradictions between Joyce's own Parnellite and socialist allegiances”. ${ }^{14}$ Fairhall is confident in deducing that the election in Dubliners "[p]lainly, then [...] invokes or assumes the circumstances and issues of the actual municipal elections in January 1902 and 1903, in particular Connolly’s campaign in the Wood Quay Ward”. ${ }^{15}$ Anne Fogarty expands on this reading in her 2006 essay "Parnellism and the Politics of Memory: Revisiting “Ivy Day in the Committee Room,”” which Gibson and Platt include in their volume as an example of historical criticism at the "Irish end" ${ }^{16}$ of its Britain-Ireland axis, furthering the view that the story details the "psychic effects" of the Home Rule debate post-Parnell and what she presents as the diverse alliances of liberalism, Unionism and nationalisms collectivised under him, along with the changing political landscape as new forces, including socialism, began to take hold and diffuse Parnellism into competing strands. ${ }^{17}$ Fogarty concurs with Fairhall in suggesting that through the figure of the socialist Colgan, "Joyce indirectly shadows a vital feature of the political landscape of contemporary Dublin in which a nascent socialism endeavoured under the aegis of Connolly to make its mark and to grapple with the problems of poverty, injustice, and alcoholism”. ${ }^{18}$ By focusing on the commemoration day of Parnell's anniversary as a scene through which the role of memory might be examined, it is suggested that Joyce experiments with a temporality of historical events from 1892-1902 in order to bring them into continuum; among the events and figures thus represented in the story, Fogarty suggests Connolly is present not only in the figure of Colgan but through the incorporation of his writings into "Ivy Day in the Committee Room,” with particular reference to his post-election briefings in Workers' Republic on his defeat in the Wood Quay ward. ${ }^{19}$ Like Fairhall, she too uses a rhetoric of disclosure when referring to Connolly's presence in the story, suggesting that while it is informed by Parnellism, there are "other resonant silences and absences that are equally palpable and of the moment," and that Connolly "implicitly permeates the narrative in a more substantial fashion than might at first appear to be the case". ${ }^{20}$ Fogarty traces this to the accusations of corruption Connolly levelled at his opponents in 1902 and 1903 in his articles, and particularly his critique of the means by which the Home Rule candidate P. J. McCall enticed voters through the provision of alcohol on election night: in these she sees the tropes of "Ivy Day" explicitly echoing Connolly's writing, and extends the reference by stating that his use of satirical poetry in his journalism is "obliquely mirrored" in the structure of Joyce's story, which also combines political prose and verse, such that through these allusions "affecting and appropriating the style and political manner of Connolly, Joyce thus counterpoints the ideals of socialism with those of Parnellism”. ${ }^{21}$ Mangianello focuses on the Connolly-Joyce nexus in relation to Arthur Griffith and the syndicalist Arturo Labriola; like Fairhall and Fogarty later on, he does so with recourse to "Ivy Day in the Committee Room,” but also draws on comments made by Joyce in his letters with regard to Griffith's silence on the question of the Irish proletariat, ultimately surmising that "political independence was not 
enough, [...] Joyce desired socialism in an Irish context, the very thing James Connolly had been trying to initiate”. ${ }^{22}$ As such, Mangianello draws a direct line between Joyce and Connolly that is subtly refined in later readings.

Curiously, given his historical methodology, Andrew Gibson himself alludes in several of his works to Connolly's influence on Joyce but leaves the historical detail and empirical evidence of that influence impalpable even as it is asserted. In James Joyce (2006) Gibson has recourse to Connolly's reference to the "compromise bargain" the Church in Ireland made with British forces, in order to provide a bridge into the statement that "Connolly was influential on the young James Joyce, and Joyce's fictional alter ego, the young Stephen Dedalus, makes Connolly’s point in Ulysses”. ${ }^{23}$ The influence Gibson claims is however not expanded upon, remaining instead as an intriguing will-to-connection in his text which recurs later on when discussing the Easter Rising, about which Gibson avers that, while Joyce was not aligned with the sacrificial nationalism espoused by Patrick Pearse, "he had been sympathetic to Connolly". 24 In a further claim, Gibson states that Joyce was briefly interested in the Irish Republican Socialist Party, the party Connolly led, a point traced back to Peter's Costello's biography of Joyce. We might pause here to cross-reference with Joyce's "Wandering Rocks", a 2002 work of criticism edited by Gibson and Steven Morrison in the European Joyce Studies series, in which Gibson makes several mentions of Connolly, citing from his works, and wherein he makes an interesting statement regarding Connolly and commemoration. In a note, he cites two of the institutions dominating Ireland - private property and class hierarchy - to which Connolly refers in his famous statement on the putative end of colonialism, stating that for Connolly these are antithetical to "Brehon law and the communal structures of Gaelic civilization” and remarking that

[i]t seems to me that Joycean aesthetics have yet to be properly read in relation to this particular thought - in other words, with an adequate sense of the (Irish, or rather, Gaelic) specificity of Connolly's socialism, and with serious reflection on how far Joyce might have shared it. ${ }^{25}$

In a reflection on the elisions and silences surrounding Connolly such as this essay is, dramatising in Joyce what is manifest in his historical legacy, the elision of Connolly's birthplace when discussing Brehon law and the influence of Scotland upon his socialism (and thus on Joyce's?... the question remains implicit) is another that should be marked. Gibson takes up this thread again in Joyce's Revenge: History, Politics, Aesthetics in Ulysses (2002), returning to cite Connolly's writings on the history of Catholic involvement with the British State in Ireland - here, in "Labour, Nationality and Religion” (1910) - from which he infers that "[i]t is clear from Joyce's work that he would have endorsed much of it". ${ }^{26}$ One example given for the demonstration of this Church-State complicity, the critique of which is according to Gibson influenced by Connolly, is the figure of Father John Conmee, S.J. in "Wandering Rocks". Regarding Conmee, Gibson reasserts the view forwarded elsewhere in his writings that he represents "the latest historical incarnation of the “compromise bargain” that, for Joyce, as for Connolly, Séan O’Faolain and others, the Church had repeatedly made with the Ascendancy and/or the British throne". ${ }^{27}$ Connolly's putative influence on Joyce is therefore again made present obliquely through a triangulation with the historical personage of Conmee fictionalised within the text. Later in Joyce's Revenge, the empirical cedes again to the conjectural when Gibson writes that Connolly’s “ideas and vocabulary are most likely to have reached Joyce between 1897 
and 1903" and that, furthermore, Stephen Dedalus repeats in "Wandering Rocks”, "at a psychologically crucial moment," what Gibson identifies in "Socialism and Nationalism" and "Socialism and Irish Nationalism" as one of Connolly's key terms of the period: "misery" ${ }^{28}$ He bases the assertion on claims made in Peter Costello's biography of Joyce, in which Costello claims that in 1903 Joyce became "involved in the affairs of a small Socialist group that met in rooms above 6 Liffey Street": the IRSP, founded by Connolly. ${ }^{29}$ Costello does not however evince detail nor evidence of that involvement which could be extrapolated into an influence, except to say that Joyce never met Connolly, who had already left for America.

A further link between the two Jameses is introduced by Gibson in the footnote reference to Costello from which the inference of Joyce's knowledge of Connolly is drawn, where it is noted that “[1]ike Joyce's, Connolly's project partly involved opening up nationalist tradition insofar as it was monolithic"; ${ }^{30}$ although the analysis is, according to the principles of the "London method," founded in an historical exegesis of the period in which Ulysses is set, rather than that in which it was written, the broad implication of one in the other again feels evoked, rather than historically grounded in particulars, evidence of a desire for connection forged in the criticism. Gibson locates the Connolly-Joyce affiliation in a shared project of the creation of Ireland, one achieved through political and the other through aesthetic means. Despite acknowledging that “Joyce's and Connolly's projects were obviously distinct” he concludes that the colonial critique "in some ways [...] moves in Connolly's direction, affectively if not ideologically". ${ }^{31}$ One might say the same for the London method in this respect.

What this demonstrates is not by any means that the assertions are themselves incorrect - their conjecture is bounded by reasonable inference - but that the historicising impulse is impelled by a drive to connect Connolly with Joyce that supersedes history itself, or at least direct historical evidence. One might infer that the historical method, designed to legitimise the study of fiction through a mode of inquiry that privileges empirical fact, in actuality requires literature to construct the history that appears to precede and already to ground the historical method by which it is interpreted. A similar rhetoric is also the predicate for Fairhall's hypotheses on the influence of Connolly upon Joyce: an historical conditional, as it were. He notes that Joyce was fourteen when Connolly founded the ISRP, and that the former left Ireland after the 1903 elections, as did Connolly, but nevertheless concludes that "[s]till, the chances are excellent that Joyce heard him speak, either during his two election campaigns or at his regular soapbox appearances”. ${ }^{32}$ Fairhall further cites Connolly's leading of protests against the Queen Victoria Diamond Jubilee and the Boer War, as well as his anti-war campaigning, as evidence that "[t]hese doings alone would be solid grounds for assuming Joyce's familiarity with Connolly's career and principles”. ${ }^{33}$ He makes a similar claim to support his reading of Joyce's Parnellism and its middle-class foundations; quoting Connolly's famous statement in "Socialism and Nationalism” (1897) regarding the hoisting of the flag over Dublin Castle in reference to the perpetuation of bourgeois class interests, Fairhall concludes that "Joyce, an avowed socialist for many years, must have heard or read similar statements by Connolly and other left-wing thinkers”. ${ }^{34}$ He also however regards that socialism as having been tempered by the outbreak of war, a fact he alludes to in rationalising Joyce's “response - or lack of one” to Connolly. ${ }^{35}$ Like Fogarty, who develops his claims, Fairhall considers 
anticlericalism and treating ${ }^{36}$ to be thematics of "Ivy Day" on the basis of their being shared concerns of both Connolly and Joyce, but he also adduces the issue of slum ownership as a further context between Connolly and those already detected in Joyce, concluding that "class interest rather than individual corruption as a source of injustice was always Connolly's main text, and it is Joyce's subtext”. ${ }^{37}$ As already shown, both Fairhall and Fogarty make the link between Connolly and Colgan, but both also depict it as a penumbrous allusion; moreover, it is one which each of the essays makes in equally penumbrous language, thereby tacitly acknowledging it as such. For Fogarty, "through the offstage, fictional figure of Colgan, Joyce indirectly shadows a vital feature of the political landscape of Dublin" ${ }^{38}$ and Connolly's story is "shadowed in the offstage presence of Colgan”. ${ }^{39}$ While Fairhall acknowledges that the equation is not absolute, he nonetheless states that "beyond doubt Connolly's solid, historical reality underlies the vague, absent figure of the Labour candidate in 'Ivy Day"”. ${ }^{40}$ Fairhall reconciles this lack by metonymising it as a "significant absence” representative of what he sees as Joyce's political position, caught between Parnell and socialism. ${ }^{41}$ He characterises these as mutually exclusive, concluding that "Joyce's ideological bias caused him to focus on one while relegating the other to a shadowy subtext that reflected political reality all too well”. ${ }^{42}$ Nuancing Fairhall's position, Gibson returns to "Ivy Day" in The Strong Spirit to argue that the story emphasises the gap between Connolly's political theory and the political reality of Dublin at the time. While Gibson agrees that the shade of Connolly adumbrates "Ivy Day," he also notes that it diverges from Connolly in rejecting both a Marxist line and a vision of working-class solidarity. ${ }^{43}$ Beyond Colgan, Gibson claims that the figure of Connolly is in fact made present through that of another character, Hynes, because it is he who, like Connolly, advocates direct speech and action within an otherwise pervasive atmosphere of equivocation between British and nationalist allegiance that characterised the Dublin bourgeoisie of the period. ${ }^{44}$ Gibson is at pains not to overstate Connolly's influence, suggesting instead that he occupies a place within a spectrum of Irish socialism: "Connolly functioned within a left Irish politics which was not incidental to the Dublin the young Joyce knew, and did not need Connolly (or the Easter Rising) to put it together with nationalism". ${ }^{45}$ He is, however, confident in developing the point made elsewhere that "Joyce's biographical links with Connolly are familiar from Costello, Fairhall, and others," ${ }^{46}$ leading to the intratextual conclusion that "Hynes's analysis of the political situation is so far like Connolly's as to make it obvious that Joyce had Connolly specifically in mind" ${ }^{47}$ Ultimately, Gibson concludes that "Ivy Day" is "Joyce's sober caution to Connolly," depicting as it does a Dublin still caught between an older, "heroic” and individualistic mode of politics and the modern, collective class politics propounded by Connolly. ${ }^{48}$ Gibson presents the latter as nonetheless under threat of becoming another romantic mythology of the type rejected by Joyce, which resonates with late twentieth-century narratives of the Rising as a blood-sacrifice now being countered in the centenary commemorations by alternative readings stressing the necessity of the Rising as direct political action.

The means by which an absence may be constituted as presence could be extracted into an observation applicable across the Joycean criticism here presented, a politics of reading that materialises Connolly's ghost in the text insofar as it is both political in its evocation of Connolly, and also as critical approaches are subject to and constitutive of the internal politics of a disciplinary field. The feint which 
allows the "solid, historical" (to echo Fairhall) and the shade and absence of evocation to confirm each other is a strategy that reappears throughout the criticism on Connolly in Joyce; it might be concluded that this evinces an a priori perspective on Irish history that places one historical reality, that of Connolly, into the sphere of an historicised account of Joyce such that both the historical and modern readings, the London and the Irish, are justified.

Both Emer Nolan and Dominic Mangianello discuss the Rising in the wider context of Joyce's nationalism and socialism respectively; discussions of the relation of Joyce to Connolly inevitably include these, but there is also, as Nolan notes, the driver of critical context through which such issues are refracted..$^{49}$ I would suggest the obverse is also true, and in the course of this article I argue that political context offers a view on the critical context of Joyce studies. The 2016 centenary, as anniversary of the Rising, the death of Connolly, and the publication of A Portrait of the Artist as a Young Man, offers a timely moment in which to consider how a politics of commemoration more commonly considered in relation to the legacy of the Rising can be read as operative within the literary sphere of Joyce studies. Trevor L. Williams adds an interesting gloss to misappropriations of Connolly in Reading Joyce Politically (1997) when discussing the aftermath of the Karl Radek controversy (wherein Joyce was criticised as a "decadent” by Radek at the First Congress of Soviet Writers) ${ }^{50}$ and the reclamation of Joyce by the critical left as evinced in Alick West's essay on Ulysses in his collection of essays entitled Crisis and Criticism (1937); Williams examines West's charge that, by refusing to align with nationalism, Joyce was ultimately aligned with conservative religious and state forces. ${ }^{51}$ What is more interesting, however, is that he refutes it by drawing on Colin MacCabe to argue that Joyce was eschewing Connolly's position, a canard handed down and typified by Seán O'Casey's 1916 pronouncement - which MacCabe, coincidentally, also adduces in evidence $-{ }^{52}$ that "Jim Connolly had stepped from the narrow byway of Irish socialism onto the broad and crowded highway of Irish nationalism". ${ }^{33}$ This view of Connolly as a traitor to socialism is echoed by Williams in defence of Joyce when he engages again with MacCabe in suggesting that "Joyce could hardly be expected to throw in his lot with the nationalists when James Connolly, the great socialist leader, by doing precisely that, abandoned proletarian internationalism in favour of a repressive nationalism”. ${ }^{54}$ The centenary commemoration of 1916 has offered the opportunity to resituate Connolly by refuting such codifications of his position and, in terms of Irish-Scottish connections, foregrounding the importance of Scotland in contextualising his political theory and action. ${ }^{55}$ It also however comes in the wake of the 2014 Scottish Referendum, in which the question of self-determination as a route to socialism was prevalent; in this, our own historical context allows that of Connolly to be reappraised along parallel lines, eschewing the argument that is here repeated and extended to Joyce, that national independence is necessarily incongruous with socialist solidarity.

In a timely article recently published in a special issue of Moving Worlds dedicated to essays on the centenary, Richard Barlow addresses the subject of Joyce and the Rising and concludes that "[t]he issue [...] is perhaps best thought of in terms of absences and disappearances,” specifically of Joyce the artist in exile and the lack of a definitive statement on the Rising in his work; Barlow situates his silence in terms of what he argues is Joyce's view of history, namely that no historical event is unique but is merely a repetition of 
prior such events - meaning therefore that historical time is collapsed into present and future time - and, moreover, in the surprise that the historical event of the Rising caused Joyce, who had conceived of Dublin as a centre of paralysis and thus incapable of such action in the period. ${ }^{56}$ This silence is voiced and appraised by Joycean criticism at the same time as it is supplemented by it. In the critical genealogy traced in this essay, historical claims are rooted in educated inference and textual analysis that is revelatory not only of a Joyce-Connolly link but of criticism's desire to commemorate Connolly in Joyce by grafting an history of Connolly onto an historicised account of Joyce. Joyce himself is a politicised figure within the literary discipline: constellations of debate and methodologies, often competing, coalesce around his work, and those positions are political in their own right. When criticism is itself made subject to historical materialism, the claims of history are seen to intersect with those of the historical method. Thus it is not only within the work of Joyce that Connolly might be found but in that of Joyce studies, implicated in a complex textual and analytical politics of lacunae and commemoration which extends to the act and debts of criticism itself; furthermore, these internal politics of commemoration can be seen to merge with an external politics that is particularly visible in this centenary year. 


\section{Notes}

${ }^{1}$ Gibson and Platt, Joyce, Ireland, Britain, 15.

2 Joyce, Finnegans Wake, 303. 8-12.

${ }^{3}$ Joyce, Ulysses, 1.648-49.

${ }^{4}$ Gibson and Platt, Joyce, Ireland, Britain, 15.

${ }^{5}$ Gibson and Platt, Joyce, Ireland, Britain, 18.

${ }^{6}$ Gibson and Platt, Joyce, Ireland, Britain, 18.

${ }^{7}$ Gibson and Platt, Joyce, Ireland, Britain, 14.

${ }^{8}$ Gibson and Platt, Joyce, Ireland, Britain, 15.

${ }^{9}$ McGreevy, "1916 Rising an Event of World Importance".

${ }^{10}$ McHugh, Annotations to Finnegans Wake, 73 and 303. Richard Barlow notes that this list is in chronological order, with Parnell situated between and mediating the political eras of O'Connell and Connolly: see Barlow, "Silent Exile? James Joyce and the Easter Rising", 22 and 28, n. 39. For the Joycean perspective on Parnell, see "The Shade of Parnell”, written in Trieste in 1912 for Il Piccolo della Sera, and collected in Barry (ed.), Occasional, Critical, and Political Writing.

${ }^{11}$ See Fairhall, James Joyce and the Question of History, 99; and Joyce, Finnegans Wake, 214.18.

${ }^{12}$ Fairhall, James Joyce and the Question of History, 92.

${ }^{13}$ Ibid.

${ }^{14}$ Fairhall, James Joyce and the Question of History, 93.

${ }^{15}$ Fairhall, James Joyce and the Question of History, 103.

${ }^{16}$ Gibson and Platt, Joyce, Ireland, Britain, 22.

${ }^{17}$ Fogarty, "Parnellism and the Politics of Memory", 105; 116.

${ }^{18}$ Fogarty, "Parnellism and the Politics of Memory", 108.

${ }^{19}$ See Fogarty, "Parnellism and the Politics of Memory", 115.

${ }^{20}$ Fogarty, "Parnellism and the Politics of Memory", 117.

${ }^{21}$ Fogarty, "Parnellism and the Politics of Memory", 117.

${ }^{22}$ Mangianello, Joyce's Politics, 127-28.

${ }^{23}$ Gibson, James Joyce, 24.

${ }^{24}$ Gibson, James Joyce, 110.

${ }^{25}$ Gibson, "Macropolitics and Micropolitics in "Wandering Rocks", 49, n. 40.

${ }^{26}$ Gibson, Joyce's Revenge, 84.

${ }^{27}$ Gibson, Joyce's Revenge, 85.

${ }^{28}$ Gibson, Joyce's Revenge, 91.

${ }^{29}$ Costello, James Joyce: The Years of Growth, 214-15.

${ }^{30}$ Gibson, Joyce's Revenge, 91, n. 43.

${ }^{31}$ Gibson, Joyce's Revenge, 97.

${ }^{32}$ Fairhall, James Joyce and the Question of History, 96.

${ }^{33}$ Fairhall, James Joyce and the Question of History, 96.

${ }^{34}$ Fairhall, James Joyce and the Question of History, 145.

${ }^{35}$ Fairhall, James Joyce and the Question of History, 182.

${ }^{36}$ Treating is a form of electoral corruption, involving the practice of providing hospitality during an election with the intention to influence voting.

${ }^{37}$ Fairhall, James Joyce and the Question of History, 103.

${ }^{38}$ Fogarty, "Parnellism and the Politics of Memory", 108.

${ }^{39}$ Fogarty, "Parnellism and the Politics of Memory", 117.

${ }^{40}$ Fairhall, James Joyce and the Question of History, 103-104.

${ }^{41}$ Fairhall, James Joyce and the Question of History, 105.

${ }^{42}$ Ibid.

${ }^{43}$ Gibson, The Strong Spirit, 50.

${ }^{44}$ Gibson, The Strong Spirit, 49.

${ }^{45}$ Gibson, The Strong Spirit, 45.

${ }^{46}$ Gibson, The Strong Spirit, 48.

${ }^{47}$ Gibson, The Strong Spirit, 49.

${ }^{48}$ Gibson, The Strong Spirit, 52.

${ }^{49}$ Nolan, James Joyce and Nationalism, 14.

${ }^{50}$ See Trevor L. Williams, Reading Joyce Politically, 14.

${ }^{51}$ See Trevor L. Williams, Reading Joyce Politically, 18-23.

${ }^{52}$ See MacCabe, James Joyce and the Revolution of the Word, 168. 


\footnotetext{
53 Seán O’Casey, The Story of the Irish Citizen Army, 52.

54 Trevor L. Williams, Reading Joyce Politically, 20.

${ }^{55}$ See Lusk and Maley, Scotland and the Easter Rising.

${ }^{56}$ Barlow, “Silent Exile? James Joyce and the Easter Rising”, 24-25.
}

\section{Bibliography}

Barlow, Richard. “Silent Exile? James Joyce and the Easter Rising.” Moving Worlds vol. 16, no. 1 2016: 17-29.

Cheng, Vincent. Joyce, Race and Empire. Cambridge: Cambridge University Press, 1995.

Connolly, James. Selected Political Writings. Edited by Owen Dudley Edwards and Bernard Ransom. London: Jonathan Cape, 1973.

Selected Writings. Edited by Peter Berresford-Ellis. London: Pluto Press, 1997.

Costello, Peter. James Joyce: The Years of Growth 1882-1915. New York, NY: Pantheon Books, 1992.

Dangerfield, George. “James Joyce, James Connolly and Irish Nationalism.” Irish University Review vol. 16, no. 1 (Spring, 1986): 5-21.

Doyle, Roddy. A Star Called Henry. London: Vintage, 2005.

Fairhall, James. James Joyce and the Question of History. Cambridge: Cambridge University Press, 1993.

Fogarty, Anne. "Parnellism and The Politics of Memory: Revisiting “Ivy Day in the Committee Room”.” In Joyce, Ireland, Britain, edited by Andrew Gibson and Len Platt, 104-121. Gainesville, FLA: University of Florida Press, 2006.

Gibbons, Luke. Joyce's Ghosts: Ireland, Modernism and Memory. Chicago, IL: University of Chicago Press, 2015. Gibson, Andrew. Joyce's Revenge: History, Politics and Aesthetics in Ulysses. Oxford: Oxford University Press, 2002. . "Macropolitics and Micropolitics in "Wandering Rocks".” In Joyce’s "Wandering Rocks”, edited by

Andrew Gibson and Steven Morrison, 27-56. Amsterdam and New York, NY: Rodopi, 2002. and Len Platt (eds.). Joyce, Ireland, Britain. Gainesville, FLA: University of Florida Press, 2006. . James Joyce. London: Reaktion, 2006.

The Strong Spirit: History, Politics and Aesthetics in the Writings of James Joyce. Oxford: Oxford

University Press, 2013.

Lusk, Kirsty and Willy Maley (eds.). Scotland and the Easter Rising. Edinburgh: Luath Press, 2016.

O’Casey, Seán. The Plough and the Stars. London: Faber and Faber, 2001.

O’Casey, Seán. The Story of the Irish Citizen Army. Hawaii: University Press of the Pacific, 2003.

Joyce, James. Finnegans Wake. New York, NY: Viking Press, 1939.

. A Portrait of the Artist as a Young Man. The definitive text corrected from Dublin Holograph by Chester G. Anderson and edited by Richard Ellmann. New York, NY: Viking Press, 1964.

Press, 1969. Dubliners: Text, Criticism, and Notes, ed. Robert D. Scholes and A. Walton Litz. New York, NY: Viking

----.-. Ulysses. Edited by Hans Walter Gabler et al. London: The Bodley Head, 1986.

Occasional, Critical, and Political Writing. Edited with an Introduction and Notes by Kevin Barry and

Translations from the Italian by Conor Deane. Oxford: Oxford University Press, 2000.

Mangianello, Dominic. Joyce's Politics. London: Routledge and Kegan Paul, 1980.

MacCabe, Colin. James Joyce and the Revolution of the Word. London and Basingstoke: The MacMillan Press Ltd., 1979.

MacDiarmid, Hugh. Selected Poetry. Edited by Alan Riach and Michael Grieve. Manchester: Fyfield and Carcanet, 2012.

MacLean, Sorley/ MacGill-Eain, Somhairle. Collected Poems. Edited by Christopher White and Emma Dymock.

Edinburgh: Polygon and Birlinn, 2011.

McGreevy, Ronan. “1916 Rising an Event of World Importance, Conference Told.” The Irish Times. 22 January 2015. http://www.irishtimes.com/culture/heritage/1916-rising-an-event-of-world-importance-conference-told-1.2075763

McHugh, Roland. Annotations to Finnegans Wake. $3^{\text {rd }}$ ed. Baltimore, MD: The Johns Hopkins University Press, 2005.

Nolan, Emer. James Joyce and Nationalism. London and New York, NY: Routledge, 1995.

Williams, Trevor L. Reading Joyce Politically. Gainesville, FLA: University of Florida Press, 1997.

Yeats, W. B. The Collected Poems of W. B. Yeats. Rev. ed. Ware, Hertfordshire: Wordsworth Books, 2000. 